\title{
PENERAPAN EMANCIPATORY QUESTION HABERMAS UNTUK MENINGKATKAN KESADARAN SEJARAH SISWA (Penelitian Tindakan Kelas Pada Pembelajaran Sejarah Di Kelas XI IPS SMA Bina Bangsa Palembang)
}

\author{
Aulia Novemy Dhita Surbakti, Mahasiswa Prodi Pendidikan Sejarah, SPs, UPI, email: \\ upidhita@yahoo.co.id
}

\begin{abstract}
ABSTRAK
Penelitian ini berjudul Penerapan Emancipatory Question Habermas untuk Meningkatkan Kesadaran Sejarah Siswa (Penelitian Tindakan Kelas Pada Pembelajaran Sejarah di Kelas XI IPS SMA Bina Bangsa Palembang). Pada hakikatnya penelitian ini dilakukan untuk memperbaiki proses pembelajaran sejarah di kelas XI IPS SMA Bina Bangsa Palembang agar dapat meningkatkan kesadaran sejarah siswa yang meliputi tiga indikator yaitu fungsi kesadaran kognitif, afektif dan kritis. Berdasarkan permasalahan tersebut metode penelitian yang digunakan adalah Penelitian Tindakan Kelas (classroom action research). Hasil penelitian menunjukkan bahwa penerapan Emancipatory Question Habermas mampu meningkatkan kesadaran sejarah siswa. Hal tersebut diketahui dari kemajuan pertanyaan dan jawaban siswa dalam proses pembelajaran dan tes hasil belajar siswa dimana kriteria siswa mengalami peningkatan dalam setiap tindakan. Adapun kendala utama penerapan Emancipatory Question Habermas adalah minimnya pengetahuah guru mitra terkait hal tersebut.
\end{abstract}

Kata kunci: emancipatory question habermas, kesadaran sejarah.

\section{PEDAHULUAN}

Pembelajaran sejarah di kelas XI IPS SMA Bina Bangsa Palembang dapat dideskripsikan diantaranya adalah siswa lebih banyak mengetahui fakta peristiwa sejarah dan beberapa siswa tidak mampu mengingat materi sejarah pada pertemuan sebelumnya. Keadaan tersebut terjadi karena guru sejarah mendominasi panggung kelas sedangkan siswa bagai penonton seperti dalam suatu pertunjukan drama. Kondisi yang terjadi di kelas XI IPS SMA Bina Bangsa tersebut seperti pemberitaan yang pernah dimuat dalam Kompas (29 Mei 2009) bahwa sejarah adalah trade mark mata pelajaran hafalan, yang dari tahun ke tahun tidak berubah dengan sistem dan metode pelajaran yang telah ditentukan dalam kurikulum. Selanjutnya diperkuat pula oleh pendapat Parrington dalam bukunya The Idea of an Historical Education (1980) yang menyatakan bahwa pengajaran sejarah sangat didominasi oleh pengajaran hafalan dengan terlalu menekankan "Chalk and Talk" (kapur dan bicara) (Damanik, 2010).

Pendidikan sejarah memang akrab dengan penyaampaian fakta-fakta sejarah. Hubungan antara fakta dan sejarah dikemukakan oleh Cohen dan Marc Depaepe (1996: 303) bahwa the fact that the history of education has finally succeeded in understanding it self as history. Penyampaian fakta dalam pembelajaran sejarah tidak bisa dihindari yang kemudian didominasi dengan penggunaan metode ceramah. Hal ini tentu saja tidak dapat dipungkiri karena untuk menganalisis suatu peristiwa sejarah maka dibutuhkan pengetahuan mengenai fakta-fakta terkait peristiwa sejarah tersebut. Namun disatu sisi keadaan ini mengakibatkan pembelajaran bersifat teacher centered atau boring learning (pembelajaran yang membosankan).

Dominasi pembelajaran dengan faktafakta sejarah dikritik pula oleh Stopsky dan Sharon Lee (dalam Supriatna E, 2006: 59) yaitu pendidikan sejarah sebagai mata pelajaran berisi 
fakta, nama dan peristiwa masa lalu; mata pelajaran yang membosankan; tidak ada kontribusi dalam masyarakat karena hanya membicarakan masa lalu; pembelajaran hanya bersumber pada buku teks; guru tidak dapat membelajarkan keterampilan berpikir dan guru IPS cenderung berasumsi bahwa tugas mereka adalah memindahkan pengetahuan dan keterampilan yang pada ada pada dirinya ke kepala siswa secara utuh (transfer knowledge to the brain of the student).

Permasalahan lain dalam pembelajaran di kelas XI IPS SMA Bina Bangsa Palembang adalah bentuk pertanyaan yang diajukan oleh guru sejarah kelas XI IPS SMA Bina Bangsa Palembang kepada siswa kelas XI IPS SMA Bina Bangsa Palembang kurang mengeksplorasi pemahaman siswa mengenai materi pelajaran. Pun sama halnya dengan siswa yang mengajukan pertanyaan sederhana seputar fakta peristiwa sejarah saja. Bukan hanya itu, dibeberapa pertemuan pembelajaran pendidikan sejarah, siswa jarang sekali bertanya walaupun guru sejarah telah memberikan kesempatan untuk bertanya. Kondisi tersebut senada dengan apa yang diungkapkan oleh Ratna Hapsari, Ketua Umum Asosiasi Guru Sejarah Indonesia (AGSI), di sela workshop "Membangun Kesadaran Sejarah untuk Kebenaran dan Keadilan" di Jakarta pada hari Jumat (29/5) (Kompas, 29 Mei 2009) bahwa para siswa dibuat sibuk menghafal tanpa memperoleh esensi sejarah itu sendiri.

Pembelajaran sejarah yang hanya diisi dengan kegiatan menghafal tahun dan peristiwa hanya akan memperkuat image pendidikan sejarah sebagai sebuah subjek yang tidak mengasyikkan dan tidak bermakna, padahal jika dikelola dengan baik pembelajaran sejarah yang sarat akan nilai dan cerita-cerita inspiratif dapat menjadi sarana hiburan edukatif bagi siswa setelah menjalani subjek-subjek lain yang cenderung menguras tenaga dan pikiran siswa seperti subjek yang penuh dengan hitunghitungan rumit.

Permasalahan yang terjadi di kelas XI IPS SMA Bina Bangsa Palembang tidak dapat dibiarkan berlangsung terus menerus karena dapat mengabaikan kesadaran sejarah siswa. Guru, terutama guru sejarah, sebagai agent of change harus memiliki kemampuan lebih dalam mengelola proses pembelajaran. Penyampaian fakta terutama dalam pembelajaran sejarah tentu saja perlu namun hal penting yang juga harus diaplikasikan adalah bagaimana penyampaian fakta yang dilakukan oleh guru sejarah tidak seputar pengetahuan fakta sejarah saja namun juga mewujudkan potensi sejarah dalam hubungannya dengan kesadaran sejarah siswa.

Mengacu pada ungkapan seorang sejarawan Inggris, Collingwood dalam bukunya The Idea of History (1973: 10) terkenal dengan pernyataan beliau yaitu:

“... knowing your self means knowing that you can do; and since nobody knows what he can do until he tries, the only clue to what man can do is what man has done. The value of history, the, is that it theachs us what man has done and then what man is..."

Ungkapan Collingwood tersebut mengandung makna bahwa mengenal diri sendiri berarti tahu apa yang dapat kita lakukan. Tidak seorang pun tahu apa yang dapat dilakukan sebelum mencoba. Satu-satunya kunci untuk tahu apa yang bisa kita lakukan adalah dari apa yang telah kita lakukan dan nilai dari sejarah adalah mengajarkan kita mengenai apa yang telah dilakukan.

Sejarah lebih dari sekedar mempersoalkan masa lalu yaitu menanyakan bagaimana masa lalu sebagai cerminan bagi masa depan manusia dalam upaya menanamkan kesadaran dan empati kesejarahan dalam konteks kekinian yang semakin mengglobal (Farisi, 2003: 76). G. Moedjanto (dalam Atmadi dan Setianingsih, 2000: 44) menambahkan bahwa ada beberapa alasan perlunya belajar sejarah yaitu adanya keinginan manusia untuk tahu masa lalu peradaban mereka, dorongan eksistensi yaitu adanya amnesia untuk menanyakan tentang asal-usulnya dan adanya dorongan legitimasi karena ingin memperoleh kedudukannya. Pada dasarnya inti dari ketiga alasan yang dikemukakan tersebut adalah mengenai identitias.

Pendidikan Sejarah selain mempelajari kehidupan atau peristiwa-peritiwa penting dimasa lampau dalam setiap sendi kehidupan dalam masyarakat dan kumpulan pengetahuan mengenai fakta sejarah, dalam rangka 
pembangunan bangsa pembelajaran sejarah bertujuan membangkitkan kesadaran sejarah siswa sehingga menciptakan kesadaran nasional yang pada gilirannya memperkuat solidaritas nasional. Sehubungan dengan hal tersebut maka pelajaran sejarah nasional sangat strategis bagi pembentukan kesadaran sejarah. Tanpa sejarah manusia tidak akan mampu membangun ide-ide tentang konsekuensi dari apa yang dilakukan dalam realitas kehidupannya pada masa kini dan masa yang akan datang dalam sebuah kesadaran historis (Aman, 2012: 229- 230).

Berdasarkan hal-hal tersebut pendidikan sejarah memegang peranan penting dalam mengembangkan kesadaran sejarah siswa seperti yang dikemukakan oleh Ismaun yaitu tujuan ideal pendidikan dan pengajaran sejarah adalah agar siswa mampu memahami sejarah dalam arti memiliki pengetahuan dan pemahaman tentang peristiwa, memiliki kemampuan berfikir krtitis, mengkaji informasi serta mengkaji setiap perubahan yang terjadi dilingkungan sekitarnya; memiliki kesadaran sejarah dalam arti memiliki kesadaran akan pentingnya waktu untuk dimanfaatkan sebaikbaiknya, kesadaran akan terjadi perubahan secara terus menerus kemampuan mengindentifikasi nilai-nilai yang terkandung dalam sejarah dan memiliki wawasan sejarah yang bermara pada kearifan sejarah.

Kesadaran sejarah dimulai dari pengetahuan mengenai peristiwa sejarah atau fakta-fakta sejarah lalu diikuti dengan kausalitas peristiwa sejarah tersebut. Tidak hanya cukup sampai disitu, kesadaran sejarah menimbulkan sikap kearifan yang tinggi dimana kita semakin bijaksana untuk menyikapi kehidupan sehingga yang terpenting adalah bagaimana belajar dari sejarah bukan bagaimana belajar sejarah. Uraian tersebut sejalan dengan ungkapan yang telah ditulis pada paragraph diatas bahwa sejarah merupakan guru kehidupan, historia magistra vitae. Untuk mencapai pada pemahaman historia magistra vitae maka diperlukan kesadaran sejarah yang dapat dicapai dalam pembelajaran sejarah. Tanpa adanya kesadaran mengenai masa lampau dan realitas yang ada didalamnya, masyarakat akan menjadi pasif bagi masa lampau mereka (Stearn, Seixas \& Wineburg, 2000: 59).
Melalui pendidikan sejarah, kesadaran sejarah berupa pemahaman mengenai kontinuitas dan perubahan yang berdaya guna untuk menyelesaikan permasalahan saat ini dan mempersiapkan masa depan sehingga dapat memberikan rasa optimis terhadap penyelesaian masalah bangsa (Wiriaatmadja, 2002: x-xi). Bahkan jauh sebelum para ahli tersebut, Rais (2008: 3) menuliskan bahwa Baginda Nabi Muhammad Salallahu'alaihi Wassalam telah menyampaikan pentingnya kesadaran sejarah:

"Barang siapa memiliki masa sekarang yang lebih bagus dari masa lalunya ia tergolong orang yang beruntung; bila masa sekarangnya sama dengan masa lalunya ia termasuk orang yang merugi; bila masa sekarangnya lebih buruk dari masa lampaunya ia tergolong orang yang bangkrut".

Melalui pembelajaran sejarah di sekolah, siswa tidak hanya disiapkan untuk mengetahui fakta-fakta sejarah namun juga untuk mengembangkan kesadaran sejarah. Kesadaran sejarah sangat esensial bagi pembentukan kepribadian dan sebaliknya. Implikasi hal tersebut bagi national building adalah sejarah dan pendidikan memiliki hubungan yang erat dalam proses pembentukan kesadaran sejarah. Dalam rangka national building pembentukan solidaritas, inspirasi dan aspirasi memiliki peranan penting untuk system-maintenance negara dan memperkuat orientasi atau tujuan negara tersebut. Tanpa kesadaran sejarah kedua fungsi tersebut sulit untuk dipacu atau dengan kata lain semangat nasionalisme tidak dapat ditumbuhan tanpa kesadaran sejarah (Kartodirdjo, 1993: 53).

Salah satu upaya untuk memecahkan permasalahan tersebut adalah dengan mengembangkan pertanyaan yang lebih dari sekedar what, when, where, why dan how tapi juga pertanyaan yang dapat menimbulkan dan mendukung pengembangan kesadaran sejarah siswa melalui konsep siswa sebagai pelaku sejarah dijamannya diantaranya adalah Emancipatory Question Habermas. Questions atau questioning (bertanya atau tanya jawab) merupakan kegiatan untuk mendorong atau membimbing siswa dan menilai kemampuan kognitif siswa. 
Adapun pemilihan pembelajaran Emancipatory Question Habermas sebagai upaya yang dilakukan untuk meningkatkan kesadaran sejarah dan memperbaiki kualitas pembelajaran adalah karena: pertama, teknik bertanya Emancipatory Question Habermas menempatkan siswa sebagai pelaku sejarah pada zamannya. Dalam hal ini kegiatan bertanya dilakukan oleh guru dan siswa dengan menggunakan teknik bertanya Emancipatory Question Habermas; kedua, teknik bertanya Emancipatory Question Habermas, merupakan strategi atau metode utama dalam pendekatan konstruktivistik untuk mengukur sejauh mana kesadaran sejarah siswa. Pendekatan konstruktivistik menekankan bahwa pengetahuan merupakan konstruksi (bentukan) manusia yang memberikan peluang pada siswa untuk membangun pengetahuannya sendiri. Selain itu pula pendekatan konstruktivistik memungkinkan siswa untuk melakukan dialog dan menggali informasi atau pengetahuan berdasarkan materi-materi atau peristiwaperistiwa sejarah sehingga siswa tidak hanya mendapatkan pengetahuan saja namun juga dengan pengetahuan yang dimiliki oleh siswa dapat meningkatkan kesadaran sejarah siswa.

Berdasarkan latar belakang tersebut penulis tertarik untuk mengambil rumusan masalah Penerapan Emancipatory Question Habermas Untuk Meningkatkan Kesadaran Sejarah Siswa (Penelitian Tindakan Kelas Pada Pembelajaran Sejarah Di Kelas XI IPS SMA Bina Bangsa Palembang).

\section{METODE PENELITIAN}

Metode penelitian yang digunakan dalam penelitian ini adalah metode Penelitian Tindakan Kelas (PTK). Metode Penelitian Tindakan Kelas (classroom action research) mengacu kepada tindakan guru ketika melaksanakan pembelajaran sebagai upaya untuk memperbaiki kegiatan pembelajaran yang telah dilaksanakan sebagaimana yang dinyatakan oleh Wiriaatmadja (2012: 75) bahwa tujuan dasar penelitian tindakan kelas adalah memperbaiki praktek pembelajaran guru di kelas. Berdasarkan hal tersebut lokasi Penelitian Tindakan Kelas ini adalah di SMA Bina Bangsa Palembang dengan subjek penelitian adalah siswa kelas XI IPS SMA Bina Bangsa Palembang dan Ibu Agustini S. Pd. Bertindak sebagai guru mitra yaitu pengajar yang melaksanakan inovasi pembelajaran. Penelitian mengenai penerapan Emancipatory Question Habermas yang bertujuan untuk meningkatkan kesadaran sejarah dibagi dalam lima tindakan yang terdistribusi kedalam tiga siklus.

Desain Penelitian Tindakan Kelas yang digunakan dalam penelitian ini adalah desain dari Kemmis dan Mc Taggart yang meliputi tahapan perencanaan (plan), pelaksanaan (act), observasi (observe) dan refleksi (reflect). Adapun teknik pengumpulan data meliputi observasi, catatan lapangan, wawancara, fotofoto dan dokumen.

\section{HASIL DAN PEMBAHASAN}

Kesadaran sejarah menunjukkan tingkat penghayatan atau pemahaman pada makna hakekat sejarah bagi masa kini dan masa yang akan datang. Kesadaran sejarah dimulai dari pengetahuan mengenai peristiwa sejarah atau fakta-fakta sejarah lalu diikuti dengan kausalitas peristiwa sejarah tersebut. Tidak hanya cukup sampai disitu, kesadaran sejarah menimbulkan sikap kearifan yang tinggi dimana kita semakin bijaksana untuk menyikapi kehidupan sehingga yang terpenting adalah bagaimana belajar dari sejarah bukan bagaimana belajar sejarah. Uraian tersebut sejalan dengan ungkapan yang telah ditulis pada paragraph diatas bahwa sejarah merupakan guru kehidupan, historia magistra vitae. Untuk mencapai pada pemahaman historia magistra vitae maka diperlukan kesadaran sejarah yang dapat dicapai dalam pembelajaran sejarah. Berdasarkan hal tersebut maka dilakukan proses pemahaman dalam mempelajari sejarah yang memberikan kesempatan kepada siswa untuk memahami, menghayati peristiwa-peristiwa sejarah melalui proses mentalnya berupa pengembangan keterampilan intelektual dan sikap ilmiah.

Kesadaran sejarah yang dimaksud dalam penelitian ini adalah mengenai fungsi kesadaran sejarah yang diperoleh dari pembelajaran sejarah meliputi fungsi kognitif, afektif dan kritis. Kesadaran kognitif adalah kesanggupan untuk mengingat, mengetahui dan melokasikan fakta sejarah serta kemampuan mengurutkan 
cerita sejarah sebagai suatu rangkaian kisah. Kesadaran sejarah afektif merupakan kesanggupan seseorang untuk mengerti makna fakta sejarah sehingga menimbulkan sikap dan semangat menyatu rasa dengan fakta tersebut. Kesadaran sejarah kritis ialah kemampuan untuk memahami, menafsirkan dan menganalisa fakta sejarah berdasarkan ukuran-ukuran kritis, rasional dan empiris. Kesadaran sejarah kritis merupakan kesadaran tertinggi bila diukur dari kesanggupan intelektual.

Emancipatory Question Habermas atau ways of knowing Habermas merupakan salah satu teknik bertanya yang merujuk pada critical theory yang dikembangkan oleh Jurgen Habermas sehinga selanjutnya disebut ways of knowing Habermas atau emansipatoris Habermas (Supriatna N, 2007: 3). Emancipatory Question Habermas yang diterapkan dalam pembelajaran sejarah ini meliputi beberapa pertanyaan yaitu pertanyaan yang berdasarkan konsep, menggunakan kata 'jika' atau if history, pertanyaan berdasarkan peristiwa kontekstual dan analogi.

Penggunaan konsep dimaksudkan untuk menghubungkan peristiwa masa lau dengan peristiwa kontekstual. Hal ini bertujuan untuk mempermudah guru dan siswa mengemukakan pertanyaan. Adapun penggunaan kata 'jika' dalam bertanya bertujuan untuk menempatkan siswa sebagai pelaku sejarah pada zamannya sehingga dalam hal ini baik guru atau siswa menemukan cara 'lain' dalam bertanya. Pertanyaan berdasarkan peristiwa kontekstual sebenarnya tidak lepas dari penentuan konsep yang akan digunakan sedangkan analogi melibatkan siswa membuat perbandingan antara kejadian masa lalu dengan masa kini atau mencari hubungan antara peristiwa masa lalu dengan masa sekarang (Supriatna N, 2007: 122).

\section{Analisis Pelaksanaan Siklus Penerapan} Emancipatory Question Habermas untuk Meningkatkan Kesadaran Sejarah Siswa

Penelitian pada Siklus 1 dibagi kedalam dua tindakan yang ditekankan pada penerapan pertanyaan berdasarkan konsep dan pertanyaan dengan menggunakan kata tanya "jika" (if history) untuk meningkatkan kesadaran sejarah siswa yang dilakukan oleh guru mitra dan siswa.

Berdasarkan hasil observasi pada Tindakan 1 yang dilakukan oleh peneliti, kemampuan guru mitra memberikan pertanyaan pada siswa berada pada kategori kurang. Hal ini karena guru mitra lebih terfokus pada bentuk pertanyaan berdasarkan konsep dan if history yang harus guru mitra ajukan pada siswa sehingga kemampuan lain yang diharapkan muncul, terabaikan. Keadaan ini wajar saja terjadi karena guru mitra masih belum beradaptasi dengan kedua bentuk pertanyaan tersebut selain karena adanya kehadiran peneliti di dalam kelas. Disisi lain keadaan tersebut memberi keuntungan yaitu adanya kemajuan guru mitra dalam menerapkan pertanyaan berdasarkan konsep dan if history jika dibandingkan dengan hasil observasi pada tahap orientasi. Sedangkan aktivitas bertanya siswa berdasarkan hasil observasi masih berada dalam kategori kurang. Hal ini bisa disebabkan oleh beberapa faktor yaitu guru mitra kurang mampu memilih materi yang menarik dan masih kurang mampu memberikan motivasi (reward) bertanya kepada siswa, berdasarkan hasil wawancara siswa masih kebingungan pada bentuk pertanyaan berdasarkan konsep dan if history.

Pada Tindakan 2 dilakukan strategi tanya jawab antar guru mitra dan siswa dengan menerapkan pertanyaan berdasarkan konsep dan if history untuk mempermudah siswa melakukan hal yang sama. Adapun jawaban siswa terhadap pertanyaan yang diajukan oleh guru mitra mulai tidak terpaku pada pengetahuan fakta. Artinya siswa mulai menemukan 'cara lain' untuk menjawab. Pertanyaan yang diajukan oleh siswa tidak lagi seputar fakta karena telah mengarah pada konsep yang disepakati dan penggunaan kata jika. Artinya, siswa mulai paham dengan dengan bentuk pertanyaan berdasarkan konsep dan if history. Namun guru mitra harus memperhatikan tanya jawab antara siswa dan teman sejawatnya karena beberapa siswa bertanya atau mengemukakan pendapatnya tidak sesuai dengan materi pelajaran walaupun pertanyaan berdasarkan konsep dan menggunakan kata jika.

Selain itu terdapat keunikan dalam proses tanya jawab pada Tindakan 2 yaitu ketika 
seorang siswa yaitu Nopen mengemukakan pendapat: "Tapi kan Jepang tidak menepati janji! Cuma janji palsu”. Pendapat Nopen tersebut berkaitan dengan apa yang dikemukakan oleh Wineburg bahwa pemahaman sejarah diperngaruhi oleh emosi selain mempengaruhi keobjektifan sejarah (Wineburg, 2006: 351). Kalimat Cuma janji palsu mewakili emosi Nopen terhadap pengingkaran janji kemerdekaan yang akan diberikan oleh Jepang kepada Indonesia. Salah satu factor yang menyebabkan emosi tersebut adalah cinta Indonesia. Hal tersebut tidak terlepas dari wawancara yang dilakukan peneliti kepada Nopen yang mengatakan bahwa sebagai orang Indonesia kita harus tau sejarah Indonesia.

Berbeda dengan Siklus 1, Siklus 2 ditujukan untuk menerapkan pertanyaan bersifat kontekstual dan analogi oleh guru mitra dan siswa untuk meningkatkan fungsi kesadaran sejarah siswa. Dalam pelaksanaannya Siklus 2 terbagi dalam dua tindakan yaitu Tindakan 3 dan Tindakan 4.

Melihat beberapa permasalahan pada Tindakan 2 maka peneliti dan guru mitra merencanakan pembelajaran untuk memperbaiki Tindakan 2 yang dilaksanakan pada Tindakan 3 . Perbaikan tersebut meliputi strategi tanya jawab akan lebih difokuskan antara siswa dengan teman sejawatnya. Adapun hasilnya, tanya jawab antara siswa dengan teman sejawat tampak responsive dan feed back. Artinya, siswa mengalami kemajuan bertanya emansipatoris atau emancipatory question habermas dengan bantuan karikatur yang diberikan oleh guru mitra sebagai petunjuk siswa untuk melakukan tanya jawab. Beberapa pertanyaan yang diajukan siswa berdasarkan konsep, if history, bersifat kontekstual dan analogi diantaranya: "Apa yang akan kamu lakukan jika kamu menjadi wakil rakyat?”; "Apa kehidupan mewah dapat mempengaruhi revolusi?"; "Apa yang akan terjadi jika rakyat mengetahui kelakuan anggota DPR seperti pada gambar?"; "Jika semua pejabat pemerintah Indonesia seperti gambar diatas, apa yang akan kamu lakukan jika mengetahui hal itu?" dan "Apakah anggota DPR yang hidup mewah dari uang rakyat bisa menyebabkan revolusi seperti di perancis?"

Guru mitra sudah tampak terlatih dan mapan dalam mengajukan pertanyaan pada siswa dengan menerapkan pertanyaan emansipatoris. Kemajuan guru mitra tampak pula pada pemberian reward kepada siswa. Adapun pemberian reward tersebut adalah berupa applause (tepuk tangan) saat berakhirnya tanya jawab antara siswa dengan teman sejawat, memberikan pujian dan menepuk pundak pada siswa yang benar menjawab pertanyaan. Menepuk pundak siswa juga dilakukan guru mitra sebagai motivasi agar siswa berani bertanya.

Pada Tindakan 4 guru mitra dan siswa telah memperlihatkan hasil yang memuaskan dalam menerapkan Emancipatory Question Habermas. Guru mitra semakin terlatih dalam menerapkan Emancipatory Question Habermas karena konsistensi guru mitra dalam menerapkan Emancipatory Question Habermas untuk meningkatkan fungsi kesadaran sejarah siswa. Kemajuan terlihat pula pada siswa dimana siswa aktif dan responsive pada pertanyaan yang diajukan oleh guru mitra.

Siklus 3 merupakan Tindakan 5 yang diarahkan pada penerapan Emancipatory Question Habermas ecara keseluruhan yaitu penerapan pertanyaan berdasarkan konsep, if history, pertanyaan bersifat kontekstual dan analogi untuk meningkatkan fungsi kesadaran sejarah siswa. Seiring berjalannya waktu dan diikuti dengan konsistensi guru mitra dan siswa menerapkan Emancipatory Question Habermas, baik guru mitra dan siswa sudah terlatih dalam menerapkan Emancipatory Question Habermas. Mengenai fungsi kesadaran sejarah siswa dapat dilihat dari tanya jawab antara Dendi dan Rio:

Dendi : “Apa yang akan kamu lakukan jika ada pejabat yang tidak mengikuti sebuah rapat yang berkaitan dengan kehidupan rakyat?"

Rio : "kalau saya presiden maka saya akan tindak lanjut anggota DPR yang tidak hadir rapat. Amanat dari rakyat harus diperjuangkan seperti semboyan demokrasi dari rakyat, oleh rakyat dan untuk rakyat. Jangan sampai rakyat menyerbu gedung DPR lagi seperti masa soeharto. Peristiwa itu kan mirip dengan 
ketika rakyat Perancis menyerbu penjara Bastille"

Jawaban Rio termasuk pada kesadaran sejarah dimana Rio memahami peristiwa sejarah yaitu penyerbuan ke penjara Bastille agar tidak terjadi hal yang sama di Indonesia, jangan sampai rakyat menyerbu gedung DPR lagi seperti masa Soeharto. Peristiwa itu kan mirip dengan ketika rakyat Perancis menyerbu penjara Bastille. Rio paham pada ungkapan "kita harus belajar dari sejarah" atau ungkapan lain "sejarah berulang" dimana pada hakikatnya inti atau esensi yang menjiwai peristiwa itulah yang berulang dan bahkan kejadian-kejadiannya sendiri secara harfiah,

Adanya kemajuan dalam menerapkan Emancipatory Question Habermas habermas untuk meningkatkan fungsi kesadaran sejarah siswa dibuktikan dari wawancara yang dilakukan oleh peneliti kepada guru mitra dan siswa. Sikap skeptic guru mitra dalam menerapkan Emancipatory Question Habermas untuk meningkatkan kesadaran sejarah siswa terkikis seiring dengan berjalannya waktu. Guru mitra tertarik untuk menerapkan Emancipatory Question Habermas untuk meningkatkan kesadaran sejarah siswa. Keunikan Emancipatory Question Habermas menunurt guru mitra adalah variasi pertanyaan yang menantang, baik guru mitra maupun siswa.

Selain dengan guru mitra, dilakukan wawancara kepada siswa secara acak untuk mengetahui pendapat siswa mengenai proses pembelajaran yang menerapkan Emancipatory Question Habermas. Adapun secara keseluruhan berdasarkan hasil wawancara, siswa menyukai pertanyaan dengan bentuk emansipatoris karena menghindari pembelajaran sejarah yang mengantuk dan membosankan. Siswa merasa ditantang untuk menjawab pertanyaan emansipatoris terutama if history karena berbeda dengan bentuk pertanyaan yang biasa digunakan guru mitra sebelum menerapkan Emancipatory Question Habermas. Kemajuan menerapkan Emancipatory Question Habermas berbanding lurus dengan peningkatan fungsi kesadaran sejarah siswa yang dibuktikan dengan peningkatan hasil belajar siswa disetiap tindakan berdasarkan tes yang telah dilakukan. Adapun persentase tes hasil belajar siswa berdasarkan indikator fungsi kesadaran sejarah siswa dapat dilihat pada Tabel 1.

Desain pembelajaran Emancipatory Question Habermas yang dapat meningkatkan kesadaran sejarah siswa pada mata pelajaran sejarah di kelas XI IPS SMA Bina Bangsa Palembang dapat dilihat pada Tabel 2.

\section{Kendalaa Penerapan Emancipatory Question Habermas Untuk Meningkatkan Kesadaran Sejarah Siswa}

Penerapan Emancipatory Ques-tion Habermas untuk meningkatkan kesadaran sejarah siswa kelas XI IPS SMA Bina Bangsa Palembang dalam pelaksanaannya ditemukan kendala-kendala yang dihadapi oleh guru mitra dan siswa yaitu guru mitra dan siswa belum memahami Emancipatory Question Habermas sehingga mengakibatkan keraguan dalam penerapannya; Terbatasnya informasi guru mitra mengenai peristiwa kontekstual. Kebutuhan terhadap informasi peristiwa kontekstual agar guru mitra agar dapat dengan mudah dikaitkan dengan materi pelajaran; kurangnya kemampuan guru mitra memberi motivasi dan reward pada siswa baik untuk bertanya atau menjawab pertanyaan. Motivasi dan reward sangat dibutuhkan sekali untuk mendukung terlaksananya penerapan Emancipatory Question Habermas dengan baik dan siswa kesulitan dalam menentukan konsep dan peristiwa kontekstual yang terkait dengan materi pelajaran sehingga perlu bimbingan guru mitra. 
Tabel 1. Indikator Persentase Fungsi Kesadaran Sejarah Siswa Kelas XI IPS SMA Bina Bangsa Palembang

\begin{tabular}{|c|c|c|c|c|c|c|c|c|}
\hline \multirow[t]{2}{*}{ Indikator } & \multicolumn{2}{|c|}{ Awal } & \multicolumn{2}{|c|}{ Siklus 1} & \multicolumn{2}{|c|}{ Siklus 2} & \multicolumn{2}{|c|}{ Siklus 3} \\
\hline & $\%$ & Kriteria & $\%$ & Kriteria & $\%$ & Kriteria & $\%$ & Kriteria \\
\hline 1 & 62 & Rendah & 78 & Tinggi & 96,5 & $\begin{array}{l}\text { Sangat } \\
\text { Tinggi }\end{array}$ & 97,6 & $\begin{array}{l}\text { Sangat } \\
\text { Tinggi }\end{array}$ \\
\hline 2 & 67 & Sedang & 80,5 & Tinggi & 86,5 & Tinggi & 92 & $\begin{array}{l}\text { Sangat } \\
\text { Tinggi }\end{array}$ \\
\hline 3 & 60 & Rendah & 66,2 & Sedang & 73,8 & Sedang & 78,7 & Tinggi \\
\hline
\end{tabular}

Tabel 2. Konstruksi Pertanyaan

\begin{tabular}{|c|c|c|c|c|c|}
\hline $\begin{array}{c}\text { Tindakan } \\
\text { Ke- }\end{array}$ & Topik & Konsep & $\begin{array}{c}\text { Pertanyaan berdasarkan konsep } \\
\text { dan If History }\end{array}$ & Peristiwa Kontekstual & Analogi \\
\hline 3 & $\begin{array}{l}\text { Revolusi } \\
\text { Perancis }\end{array}$ & Empati & $\begin{array}{l}\text { Mengapa pemimpin biasanya gemar } \\
\text { hidup mewah? } \\
\text { Apakah kebiasaan tersebut pengaruh } \\
\text { dari kehidupan di Eropa? } \\
\text { Apakah kebiasaan tersebut dapat } \\
\text { meningkatkan empati terhadap } \\
\text { kehidupan masyarakat kurang } \\
\text { mampu? } \\
\text { Apakah kebiasaan hidup mewah } \\
\text { dapat menyebabkan tindak korupsi? } \\
\text { Seperti apa seharusnya kehidupan } \\
\text { seorang pemimpin? } \\
\text { Adakah figure tersebut di Indonesia? } \\
\text { Dst. }\end{array}$ & $\begin{array}{l}\text { Korupsi sebagai salah } \\
\text { satu sebab dari kehidupan } \\
\text { mewah }\end{array}$ & $\begin{array}{l}\text { Kesamaan dan } \\
\text { perbedaan antara } \\
\text { kehidupan Maria } \\
\text { Antoinette dan Ratu } \\
\text { Atut }\end{array}$ \\
\hline
\end{tabular}

\section{PENUTUP}

Fungsi kesadaran sejarah siswa berhubungan dari hasil proses pembelajaran sejarah siswa. Salah satu cara yang dapat diterapkan untuk meningkatkan fungsi kesadaran sejarah siswa adalah dengan menerapkan Emancipatory Question Habermas dalam pembelajaran sejarah. Penerapan Emancipatory Question Habermas sesuai dengan pembelajaran dengan pendekatan konstruktivistik dimana guru berperan sebagai fasilitator, mediator dalam kegiatan belajar dan siswa sebagai pemikir (student are viewed as thinkers with emerging theories about the world).

Berdasarkan uraian pembahasan hasil penelitian dan temuan-temuan yang diperoleh peneliti mengenai penerapan Emancipatory Question Habermas untuk meningkatkan fungsi kesadaran sejarah siswa maka disimpulkan bahwa pembelajaran sejarah melalui penerapan Emancipa-tory Question Habermas mampu meningkatkan fungsi kesadaran sejarah siswa yang meliputi fungsi kognitif, fungsi afektif dan fungsi kritis dan juga melatih siswa untuk bertanya emansi-patoris. Selain itu pembelajaran sejarah melalui penerapan Emancipatory Question Habermas mampu mening-katkan keterampilan bertanya guru yang meliputi kemampuan bertanya berdasarkan konsep, bertanya menggu-nakan kata tanya jika atau if history, bertanya berdasarkan kontekstual dan analogi.

\section{DAFTAR PUSTAKA}

Aman. (2006). Kesadaran Sejarah dan Nasionalisme: Pengalaman Indonesia.[Online]. Tersedia: 
http://staff.uny.ac.id/sites/default/files/pen elitian/Dr.Aman,M.Pd./B-22KESADARANSEJARAHDANNASION ALISME.pdf [24 September 2013].

Cohen, S. dan Marc Depaepe (1996). "History of Education in The Postmodern Era". Paedagogica Historica International Journal of The History of Education. 1996 Vol. 32 (pg. 301-305).

Damanik, E. L. (2010). Keterkaitan Model dan Sumber Belajar dalam Pembelajaran Sejarah (Mengantisipasi Pembelajaran Sejarah Yang Membosankan). [Online]. Tersedia: http://pussisunimed.wordpress.com/2010/ page/10/ [29 Januari 2014].

Farisi, M. I. (2003). "Pendidikan Sejarah sebagai Pendidikan Kebangsaan yang Emansipatoris dan Membebaskan". Dalam Historia Magistra Vitae: Menyambut 70 Tahun Pro. Dr. Hj. Wiriaatmadja, M.A. Bandung: Historia Utama Press.

Kartodirdjo, S. (1993). Pendekatan Ilmu Sosial dalam Metodologi Sejarah. Jakarta: Gramedia Pustaka Utama.

Rais, M. A. (2008). Agenda Mendesak BangsaSelamatkan Indonesia!. Yogyakarta: PPSK Press.
Stearn, P. N, Peter Seixas \& Sam Wineburg. (2000). Knowing, Teaching And Learning History: National And International Perspectives. New York: New York University Press.

Supriatna, E. (2006). Upaya Meningkatkan Kesadaran Sejarah Siswa Melalui Alat Pendidikan Reward dan Punishment. Jurnal Pendidikan Ilmu Sosial. No, 26 Tahun XIV Edisi Januari-Juni 2006 (5568). Bandung: FPIPS.UPI.

Supriatna, N. (2007). Konstruksi Pembelajaran Kritis. Bandung: Historia Utama Press.

Tanpa Nama. "Payah, Sejarah kok dihafal". Kompas (29 Mei 2009).

Wineburg, S. (2006). Berpikir Historis: Memetakan Masa Depan, Mengajarkan Masa Lalu. Jakarta: Yayasan Obor Indonesia.

Wiriaatmadja, R. (2002). "Menyegarkan Kembali Model Pendekatan Inkuiri di Kalangan Pengajar Sejarah". Pendidikan Sejarah di Indonesia Perspektif Lokal, Nasional dan Global. Bandung: Historia Utama Press.

Wiriaatmadja, R. (2012). Metode Penelitian Tindakan Kelas. Bandung: Rosdakarya. 